\title{
On Medullosa centrofilis, a New Species of Medullosa from the Lower Coal Measures.
}

\author{
BY \\ E. DE FRAINE, D.SC., F.L.S., \\ Assistant Lecturer in Botany, Unizersity of Wales, Aberystwyth. \\ With Plate XV and five Figures in the Text.

\section{Contents.}

\begin{tabular}{|c|c|c|c|c|c|c|}
\hline & & & PAGE & & & PAGE \\
\hline I. & INTRODUCTION & & $25^{I}$ & VII. & AFFINITIES & - $26 r$ \\
\hline II. & General Structure & & $25^{2}$ & VIII. & DIAGNOSIS . & 263 \\
\hline III. & The Steles & - & 254 & IX. & SUMMARY & 263 \\
\hline IV. & The Leaf-TraCes & • & $25^{8}$ & $\mathrm{X}$. & LITERATURE CITED & . 264 \\
\hline V. & The Periderm & • & 259 & & Explanation of Plate & 264 \\
\hline VI. & The Leaf Bases & - & 259 & & & \\
\hline
\end{tabular}

\section{INTRODUCTION.}

THE specimen of a Medullosean stem which forms the subject of the present investigation was obtained from the colliery at Shore Littleborough in Lancashire, and is of Lower Coal Measure age, as are also the only other British species of the genus which have, up to the present, been described-namely $M$. anglica ${ }^{1}$ and $M$. pusilla. ${ }^{2}$

The coal-ball in which the stem occurred was divided by Mr. J. Lomax into three parts: from the portion named 3 a series of six transverse sections was obtained (sections $\mathrm{A}-\mathrm{F}^{3}$ ), two slightly oblique transverse sections were available from part 2 (sections $8-9^{4}$ ), and a transverse and two longitudinal sections were cut from piece I (sections $24^{5}$ and $25^{-6}{ }^{6}$ ). No information was obtained by which the distance between sections $\mathrm{F}$ and

1 Scott, D. H.: On the Structure and Affinities of Fossil Plants from the Palaeozoic Rocks. III. On Medullosa anglica, a new Representative of the Cycadofilices. Phil. Trans. Roy. Soc., Ser. B, vol. cxci, I899. (Referred to subsequently as M. anglica, loc. cit.)

${ }^{2}$ Scott, D. H. : Studies in Fossil Botany. Part II, 2nd ed., 1909; On Medullosa pusilla, Proc. Roy. Soc., Ser. B, vol. lxxxvii, pp. 22 I-8.

3 University College, London, Collection, Catalogne nos. O. $80 a, 0.80 f$.

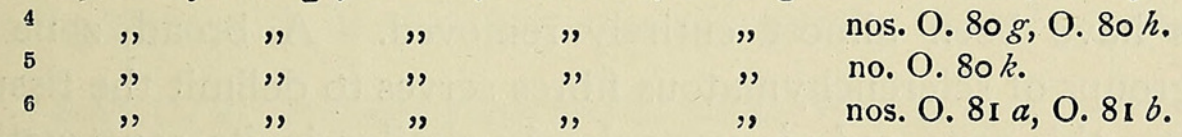

[Annals of Botany, Vol. XX VIII. No. CX. April, 1914.] 
8 , and between sections 9 and 24 , could be estimated, so that the rapidity with which the changes occurred in the series of sections could not be determined.

\section{General Structure.}

The specimen consists of a portion of a stem surrounded by adherent leaf-bases. The diameters of the stem in the topmost section are roughly $5 \mathrm{~cm} . \times \mathrm{I} \cdot 5 \mathrm{~cm}$., including the leaf-bases; this estimate of the longer diameter is certainly too low, however, for part of one of the leaf-bases has either been torn off or else destroyed at some time during the process of petrifaction. The shape of the stem with its covering of leaf-bases was thus distinctly flattened (Pl. I, Fig. I), though the form is, in all probability, exaggerate by lateral pressure.

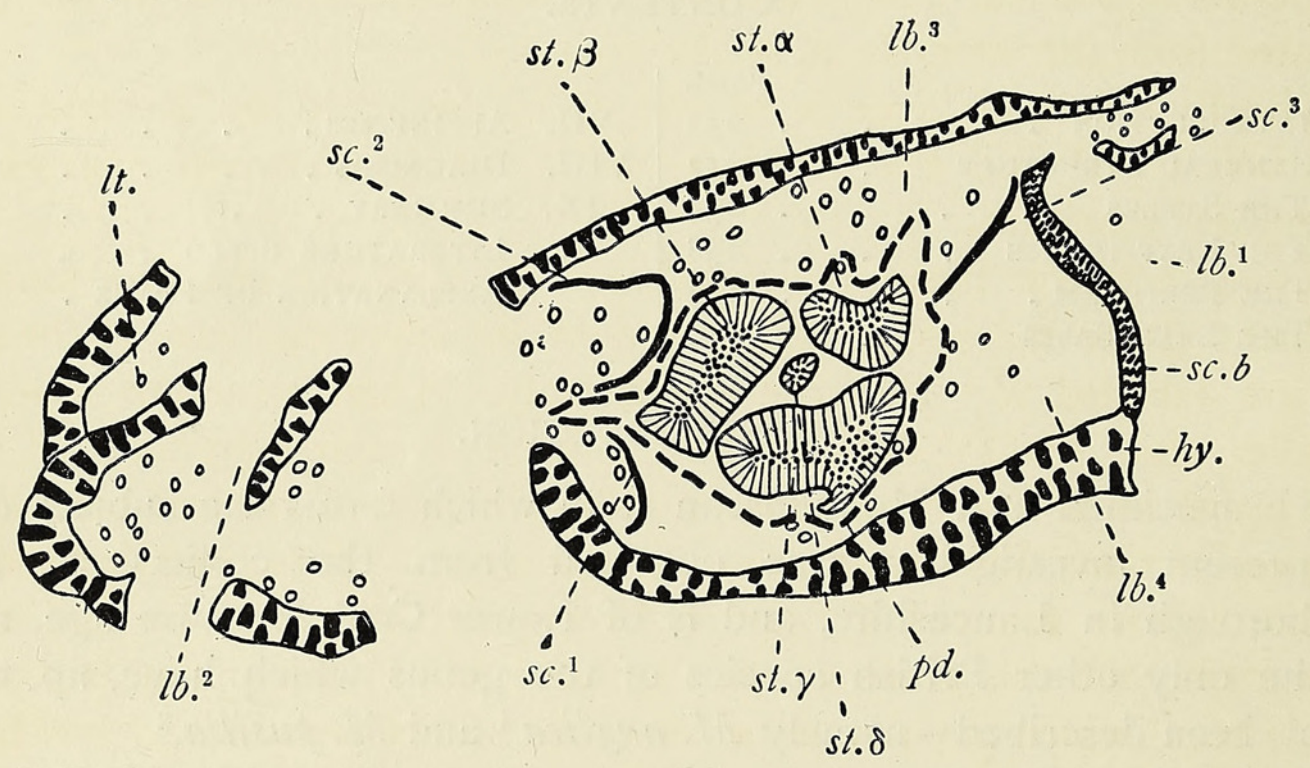

Text-FIG. I. Diagram of slide B. This diagram is intended to serve as a key to Plate XV, Fig. I. $\times 2$.

The ends of the long axis of the stem are occupied by prominent masses of tissue which represent leaf-bases, still in continuity with the stem. Practically the whole of one of these is present (lb. ${ }^{2}$, Text-fig. I), though its tissues are much displaced by the intrusion of Stigmarian rootlets; two bands of sclerenchymatous fibres, $s c^{1}{ }^{1}$ and $s c{ }^{2}$, mark the limit between the tissues of the adherent leaf-base and those of the stem proper.

Nearly opposite to this leaf-base, at the other end of the long diameter of the stem, is a second leaf-base, $l b^{1}{ }^{1}$, much less well preserved than $l b .^{2}$; its outer parts have been almost entirely removed. A broad zone of anastomosing groups of sclerenchymatous fibres serves to delimit the tissues of this leaf-base; this zone, sc.b., is very closely similar in its construction to the hypodermal layer of the leaf-base; it differs in the much more compact 
nature of the fibrous groups, the strands of parenchyma cells being larger in the hypoderma (hy.) than in the limiting band (sc.b.), and also in the fact that secretory canals are abundant in the hypodermal region, but are almost entirely absent in the limiting zone. In the sections 8 and 9, cut from portion 2 of the coal-ball, the limiting zone sc.b. is present only in the form of a band of sclerenchyma precisely similar to $s c .{ }^{1}$ or $s c .{ }^{2}$. The passage from the simple sclerenchymatous band to the more complex limiting layer sc.b. could not unfortunately be traced, since it lay between sections $F$ and 8. There can be no doubt, however, that in the lower parts of the adherent leaf-base its tissues are separated from those of the stem by a continuous sclerenchymatous layer; this layer became broken up into strands of fibres by the 'intrusion' of parenchyma tissue as the nodal region above was approached, and finally, by the increase in the parenchyma and the association of secretory canals, the limiting layer approximated to the hypoderma of the leaf-base, with which it became continuous as the petiole separated from the stem-tissue at the node.

The hypodermal layer is of the form described by Renault as the Landriotii type, ${ }^{1}$ and the leaf-base as a whole shows a characteristic Myeloxylon ${ }^{2}$ structure.

Lying between these two leaf-bases $l b .^{1}$ and $l b .{ }^{2}$ are two much less prominent tissue masses, at either end of the short diameter of the stem ; they are labelled $l b .^{3}$ and $l b .^{4}$ respectively. Their structure repeats on a smaller scale that of $l b .^{1}$ and $l b .^{2}$ : a band of sclerenchyma $\left(s c{ }^{3}\right)$ occurs in the upper sections of the series, cutting off part of the leaf-base $l b .^{3}$; in the lower sections this band cannot be made out. It is possible, of course, that the regions marked $l b .^{3}$ and $l b .^{4}$ represent the true cortical tissues of the stem, but the presence of the band $s c{ }^{3}$ in the upper part of the series, a band which appears to be characteristic of an adherent leaf-base at its lower end, would appear to render the view that they represent the extreme bases of leaves the more tenable one.

If this view be maintained, then the specimen represents a portion of a stem entirely surrounded by four spirally arranged adherent leaf-bases. No petiole becomes free from the stem during the course of the series, but a consideration of the nature of the 'limiting layer' $\left(s c .{ }^{1}, s c .{ }^{2}, s c{ }^{3}\right.$, and $s c . b$., Text-fig. I) during the series shows that the leaves left the stem in the order $l b .{ }^{1}, l b .^{2}, l b .^{3}$, and $l b^{4}{ }^{4}$. Of these, $l b .^{1}$ represents the oldest leafbase; it probably separated from the stem at a distance not very much above the level of the top section. The leaf-bases were decurrent down the stem for a considerable distance (for at least four internodes), so that in life the stem with its distant nodes presented a ribbed or winged appearance.

1 Scott, D. H. : Studies in Fossil Botany, 2nd ed., Pt. II, p. 445.

${ }^{2}$ Seward, A. C.: On the Genus Myeloxylon (Brong.) Ann. of Bot., vol. vii, p. I, March, 1893. 
In Medullosa anglica ${ }^{1}$ the leaf-bases also appeared to clothe completely the stem surface; there also they were decurrent and confluent with the stem for a great vertical distance, at least $13 \mathrm{~cm}$., so that in these respects the two plants show great similarity.

In $M$. anglica, Scott was able to determine the arrangement of the leaves, but in the present specimen this could not be definitely ascertained, but the phyllotaxis certainly does not appear to be consistent with that of $M$. anglica, where the divergence has been shown to be two-fifths.

The vascular tissues of the stem are entirely enclosed in a narrow zone of tissue $p d$., which represents the beginning of periderm ${ }^{2}$ development (Text-fig. I). The vascular system consists of an outer ring of four steles, reduced by fusion to three in the upper part of the specimen, enclosing a central stele or star-ring ( $\delta$, Text-fig. I). The greatest interest of the specimen lies in the presence of this star-ring, for hitherto such a structure has not been described in any of the Medulloseae of Lower Coal Measure age, although the Permian members of the genus Medullosa are all characterized by the occurrence of such strands. ${ }^{3}$

The structure of the steles is essentially similar in every case. The central portion of each is composed of a mass of primary tracheides intermixed with parenchyma; surrounding the primary xylem is a zone of secondary wood of variable thickness; but no phloem is preserved round any of the steles.

\section{The Steles.}

The size of the individual steles varies considerably, as the maximum dimensions of transverse sections taken from the uppermost slide, A, will show :

$\begin{array}{cc}\text { Stele } & \alpha \\ \Rightarrow & \beta \\ " & \gamma \\ , & \delta\end{array}$

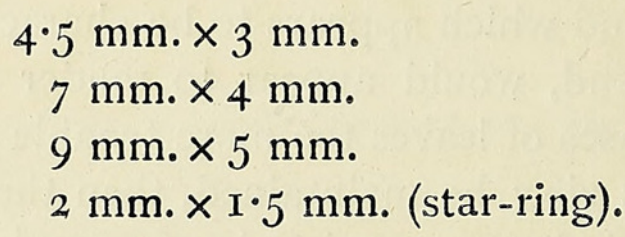

The form of the stele is somewhat irregular and varies in the course of the series; but the star-ring remains consistently oval throughout (cf. Pl. I, Fig. I and Fig. 2).

The whole of the interior of the steles is occupied by a mass of primary wood associated with thin-walled parenchymatous elements; the structure is strikingly similar to that of one of the steles of Medullosa anglica, except that there appears to be less variability between the pro-

1 M. anglica, loc. cit.

2 Scott describes an internal periderm surrounding the steles in Medullosa pusilla, p. 222.

3 Weber, O., und Sterzel, J. T. : Beiträge zur Kenntniss der Medulloseae. Ber. der Naturw. Ges. zu Chemnitz, vol. xiii, I 896 . 
portions, and in the arrangement, of the two constituents than is the case with $M$. anglica. The main bulk of the elements of the primary wood consists of multiseriately pitted tracheides which pass over almost insensibly into the similar, though somewhat smaller, elements of the secondary xylem.

Here and there towards the periphery of the primary wood occur large strands of tracheides, considerably smaller in size than the ordinary primary xylem elements, and showing spiral thickenings on their walls ( $p x y$.,

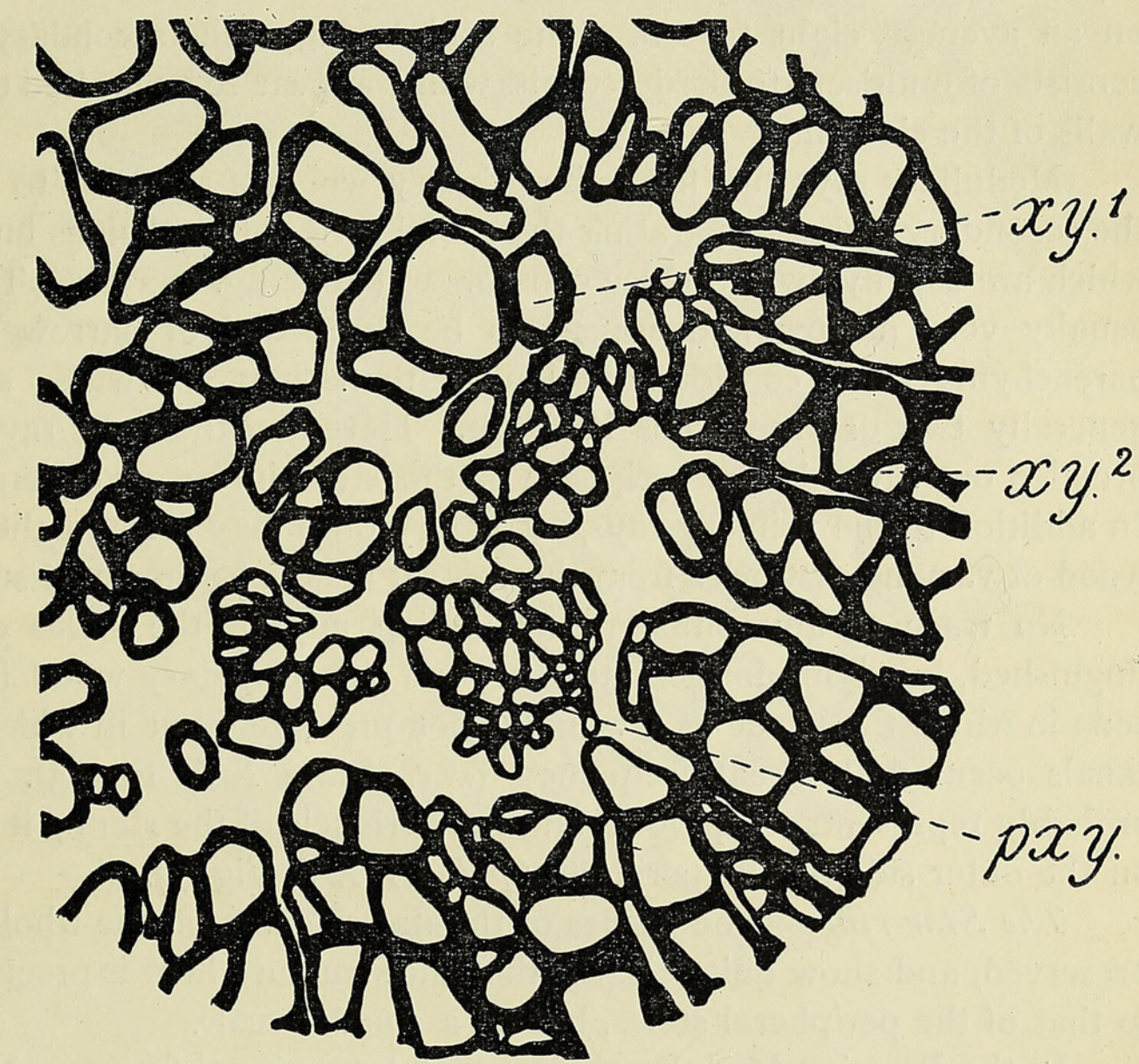

TexT-FIG. 2. Transverse section of part of stele, showing a strand of spirally thickened tracheides of the primary wood. $\times 70 . \quad x y \cdot{ }^{1}=$ primary xylem; $x y \cdot{ }^{2}=$ secondary xylem; $p x y .=$ strand of spirally marked tracheides.

Text-fig. 2). These groups evidently indicate the position of the protoxylem elements, but from transverse sections it is impossible to say with certainty whether the development of the protoxylem was strictly exarch or slightly mesarch in nature, and the longitudinal sections did not enable the point to be decided. The structure of a stele is strikingly similar to that of a stele of Medullosa pusilla, in which also the position of the protoxylem group could not be determined with certainty. In the star-ring the strand of spiral elements is represented by three or four tracheides only (as seen in oblique section), and the development of the protoxylem appears to be almost certainly exarch. It is, therefore, probably exarch in the outer ring 


\section{6 de Fraine.-On Medullosa centrofilis, a New Species of}

of steles also. The well-marked peripheral strands of spirally marked tracheides are also characteristic of the steles of $M$. anglica, but the protoxylem in this case is undoubtedly mesarch in development. ${ }^{1}$

The conjunctive parenchyma of the primary wood is composed of thinwalled tissue, which on the whole is very badly preserved.

A zone of secondary wood occurs around each stele, its dimensions vary somewhat, and the thickness is usually greater on the side of the stele adjacent to the star-ring. ${ }^{2}$ The number of secondary tracheides in a row is, on an average, eight to ten. The sculpturing of the secondary tracheides consists of multiseriate bordered pits which appear to be limited to the radial walls of the elements.

Medullary rays run from the primary wood of the stele to the limit of the secondary xylem, separating the radial series of tracheides into segments which are usually two to three cells broad (Text-fig. $2, x y .{ }^{2}$ ). The rays are usually very narrow and appear to be composed of narrow thin-walled parenchyma cells, considerably longer than they are wide; each ray is generally two or three cells in width. Here and there the rays appear to broaden out towards the periphery of the stele into wedge-shaped masses. In addition to the primary rays, secondary ones may arise in the secondary wood at varying distances from the central mass of primary tissue.

No trace of any phloem surrounding any of the steles can be distinguished, but lying immediately beyond the secondary wood is a narrow zone in which the tissue as a whole is not preserved, but in which secretory canals occur with great frequency (m.c., Plate XV, Fig. 3). This zone probably represents the phloem and the pericycle of the stem; it is bounded on the outer side by the periderm (p.d., Pl. XV, Fig. 3 ).

The Star-ring.- The tissues of the star-ring are, on the whole, very well preserved, and show quite clearly that the structure here is precisely similar to that of the peripheral steles, but on a smaller scale.

In the Permian Medullosas, in which 'star-rings' form so characteristic a feature, their preservation is, as a rule, far from good, and the structures are described as possessing a 'partial pith' surrounded by a zone of secondary wood and bast ; the 'partial pith' consists of scattered primary tracheides and parenchyma, ${ }^{3}$ though occasionally, as in $M$. Solmsii, Schenk $\gamma$ lignosa, 'die markständigen Sternringe lassen kein deutliches Centralmark mit Primärtracheiden, auch keinen äusseren Bastbelag erkennen.' ${ }^{4}$ It seems extremely probable that the star-rings of this last named species are of the

1 M. anglica, loc. cit., p. 89 .

${ }^{2}$ Cf. $M$. anglica, loc. cit., p. 89 , and $M$. pusilla, p. 223 , both ot which show a similar phenomenon.

3 Weber, O., und Sterzel, J. T. : Beiträge zur Kenntniss der Medulloseae, loc. cit., cf. Text-fig. 23, 'Sternring' of Medullosa Leuckarti, Göpp. und Stenz., with Text-fig. 9, 'Sternring' of M. stellata v. Cotta $\delta$ lignosa.

1 Loc. cit., p. 78 and Text-fig. $\mathbf{I} 3$. 
type shown in the new specimen, in which the transition from primary to secondary wood is difficult to trace even when the preservation is good.

The 'partial pith' is evidently homologous with the primary wood of the stele, but in some of the Chemnitz fossils the proportion of parenchyma to wood elements was very different from the new specimen, ${ }^{1}$ though in some cases poor preservation may account for the seeming difference. ${ }^{2}$ So

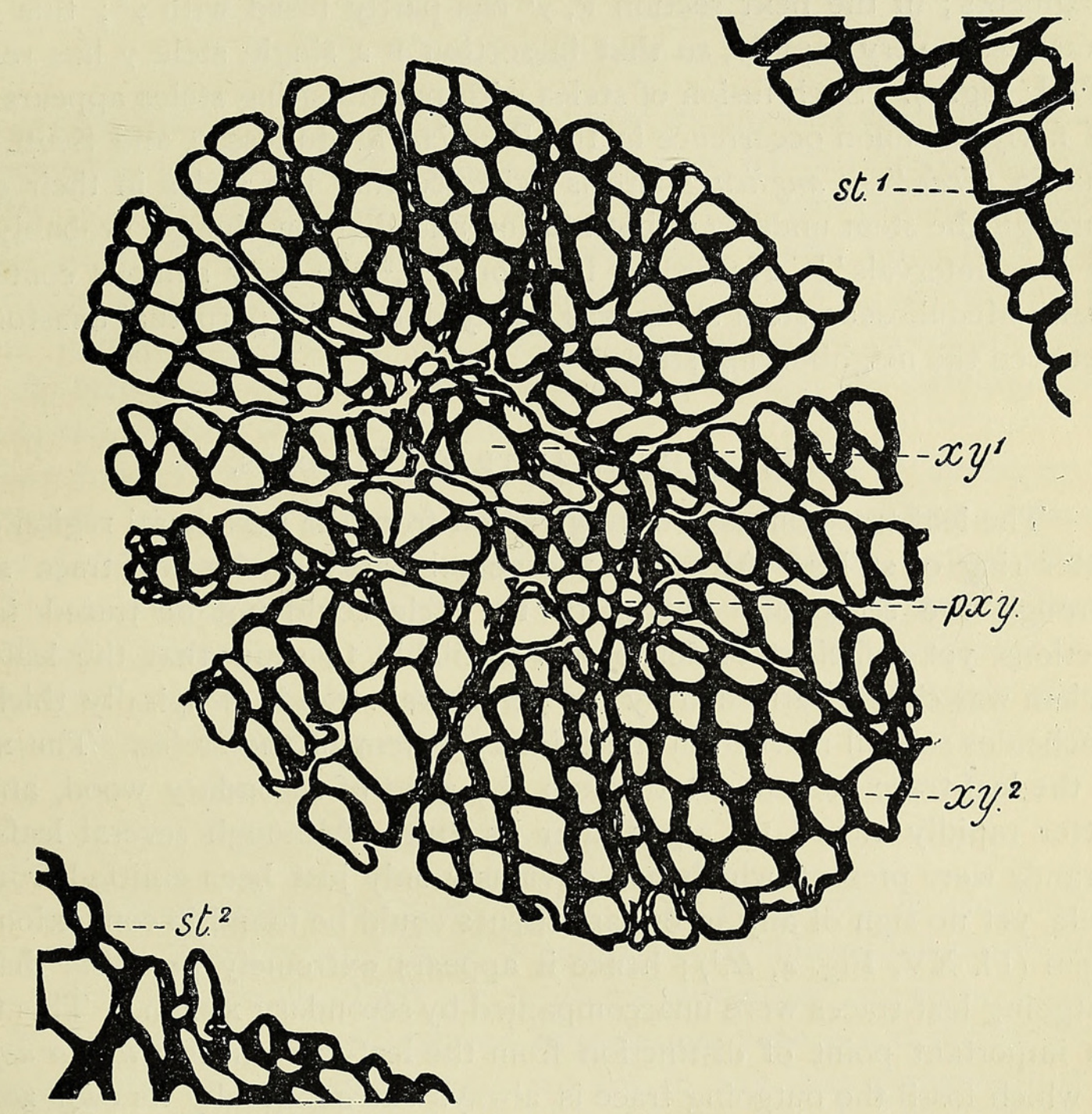

TEXT-FIG. 3. Transverse section of star-ring. $\times 53 . \quad x y .{ }^{1}=$ primary wood; $x y .{ }^{2}$ = secondary wood; $p x y$. protoxylem; st. ${ }^{1}$ and $s t .{ }^{2}=$ portions of two outer steles.

long ago as $188 \mathrm{I}$ it was pointed out by Goeppert and Stenzel ${ }^{3}$ that the star-rings differed from the peripheral steles only in size and shape, and this observation can clearly be extended to the new Medullosa also.

Course of the Steles. - The central stele or star-ring shows no change in the portion of stem which was available for investigation, so that neither its origin nor its ultimate fate could be determined.

1 Loc. cit., p. 54, Text-fig. 5 .

2 Loc. cit., p. 64 , Text-fig. 9 .

Goeppert, H. R., und Stenzel, G.: Die Medulloseae. Eine neue Gruppe der fossilen Cycadeen. Kassel, I88ז. 
In the lower sections of the series other plant tissues have so intruded into the stem that only one of the outer ring of steles is represented in entirety; this is the stele termed $a$ (Pl. I, Fig. 2), and it undergoes practically no change during the whole series; stele $\beta$ also appears to have been materially unaltered. In sections 8 and 9 , cut from the middle portion of the block, the steles $\gamma^{1}$ and $\gamma^{2}$ (Pl. II, Fig. 2) are represented by two fragments ; in the next section $\mathrm{F}, \gamma^{1}$ has partly fused with $\gamma^{2}$; this fusion takes place very rapidly, so that in section B a single stele $\gamma$ has resulted (Pl. I, Fig. I). Such fusion of steles with neighbouring steles appears to be of fairly common occurrence in the Permian Medulloseae, and Scott states that in Medullosa anglica 'there is evidence that the steles in their course through the stem underwent both fusion and division, though probably only at long intervals'. ${ }^{1}$ According to Worsdell, ${ }^{2}$ the very sinuous contour of many Medullosean stem steles was partly due to the perpetual anastomoses between the neighbouring steles.

\section{The Leaf-trace Bundles.}

The leaf-trace bundles were given off from the peripheral region of the outer ring of steles. Although the actual passage of a leaf-trace strand through the secondary tissues of the stele could not be traced in the sections, yet sufficient evidence was available to show that the leaf-trace xylem was chiefly furnished by the peripheral strands of spirally thickened tracheides so well marked in the primary xylem of the steles. The xylem of the leaf-trace passed out through the zone of secondary wood, and the latter rapidly closed up again after its exit. Although several leaf-trace strands were present, which had obviously only just been emitted from the stele, yet no sign of any secondary tissues could be found in connexion with them (Pl. XV, Fig. $\left.4, l t .{ }^{1}\right)$; hence it appears extremely probable that the outgoing leaf-traces were unaccompanied by secondary xylem. ${ }^{3}$ This forms an important point of distinction from the leaf-trace in Medullosa anglica, in which fossil the outgoing trace is always surrounded by its own zone of secondary wood and bast. ${ }^{4}$ No phloem is preserved in the stem, hence it is impossible to determine whether the outgoing strands are concentric in structure, but in any case they immediately begin to divide up into smaller collateral bundles, in which the protoxylem lies adjacent to the space representing the phloem (cf. $l t{ }^{1}$ and $l t .{ }^{2}$ in Pl. I, Fig. 4).

In the zone of ill-preserved tissue lying between the ring of steles and the periderm, a fairly extensive group of short, reticulately marked tracheides,

1 M. anglica, loc. cit., p. 91.

2 Worsdell, W. C. : The Structure and Origin of the Cycadaceae. Ann. of Bot., vol. xx, April, I906, p. I 29.

3 In $M$. pusilla the leaf-trace immediately after its exit showed 'no obvious secondary wood'.

4 Compare $M$. anglica, loc. cit., Plate II, Fig. Io. 
very like transfusion tissue, is present in section A, lying close to an outgoing leaf-trace bundle. This group is of interest when it is recalled that Scott noted in two cases in $M$. anglica ${ }^{1}$ that a leaf-trace after diverging from the stele was connected with it for a considerable distance by radial bridles of short tracheides, and he suggested that the peculiarity was correlated with the insertion of adventitious roots.

\section{The Periderm.}

A continuous zone of well-preserved tissue encloses the vascular tissues of the stem (cf. pd., Pl. I, Figs. I and 4). The zone, which is very irregular in outline, is usually about five or six cells in thickness, and the more or less regular seriation of the cells points to its secondary origin, while here and there traces of a cambium can be detected (c.b., Pl. I, Fig. 4); secretory sacs are occasionally present (m.c., Pl. I, Fig. 3). The tissue strongly recalls the secondary cortex of Sutcliffia insignis, ${ }^{2}$ though the development is far less than in that fossil.

Since none of the external tissues show sign of death or of 'drying up', it is obvious that the zone, though morphologically periderm, cannot function as does the cork of the present day. The conclusion arrived at by $\mathrm{Kisch},{ }^{3}$ in an investigation into the physiological anatomy of the periderm in the fossil Lycopodiales, applies equally well here: that, "whatever the morphological nature of the secondary tissue, there is no evidence to show that any of it was other than secondary cortex.'

\section{The Leaf-Bases.}

The leaf-bases which are present are in all cases still in continuity with the stem. Their ground tissue is composed of thin-walled parenchymatous cells, throughout which are scattered numerous secretory canals (m.c., Pl. I, Fig. 3). A well-marked hypodermal zone lies at the limit of the section, but the external layers are not in any case preserved; the hypoderma is of Renault's Myeloxylon Landriotii type (hy., Pl. I, Figs. I, 2 , and 3).

The sclerotic strands of the hypoderma are usually two, occasionally three deep, and are somewhat irregular in form; they are similar to those of Medullosa anglica; the hypoderma thus differs from the simpler form in $M$. pusilla, where usually the strands are single, at the most two deep, and at the same time more regular in form. Corresponding with the

$1 M$. anglica, loc. cit., p. 93 .

2 de Fraine, E. : On the Structure and Affinities of Sutcliffia, in the Light of a newly discovered Specimen. Ann. of Bot., vol. xxvi, No. civ, Oct. I9I2, p. 105I and Text-fig. I 7 .

3 Kisch, M. H. : The Physiological Anatomy of the Periderm of Fossil Lycopodiales. Ann. of Bot., vol. xxvii, No. cvi, A pril I9I3, p. 296. 


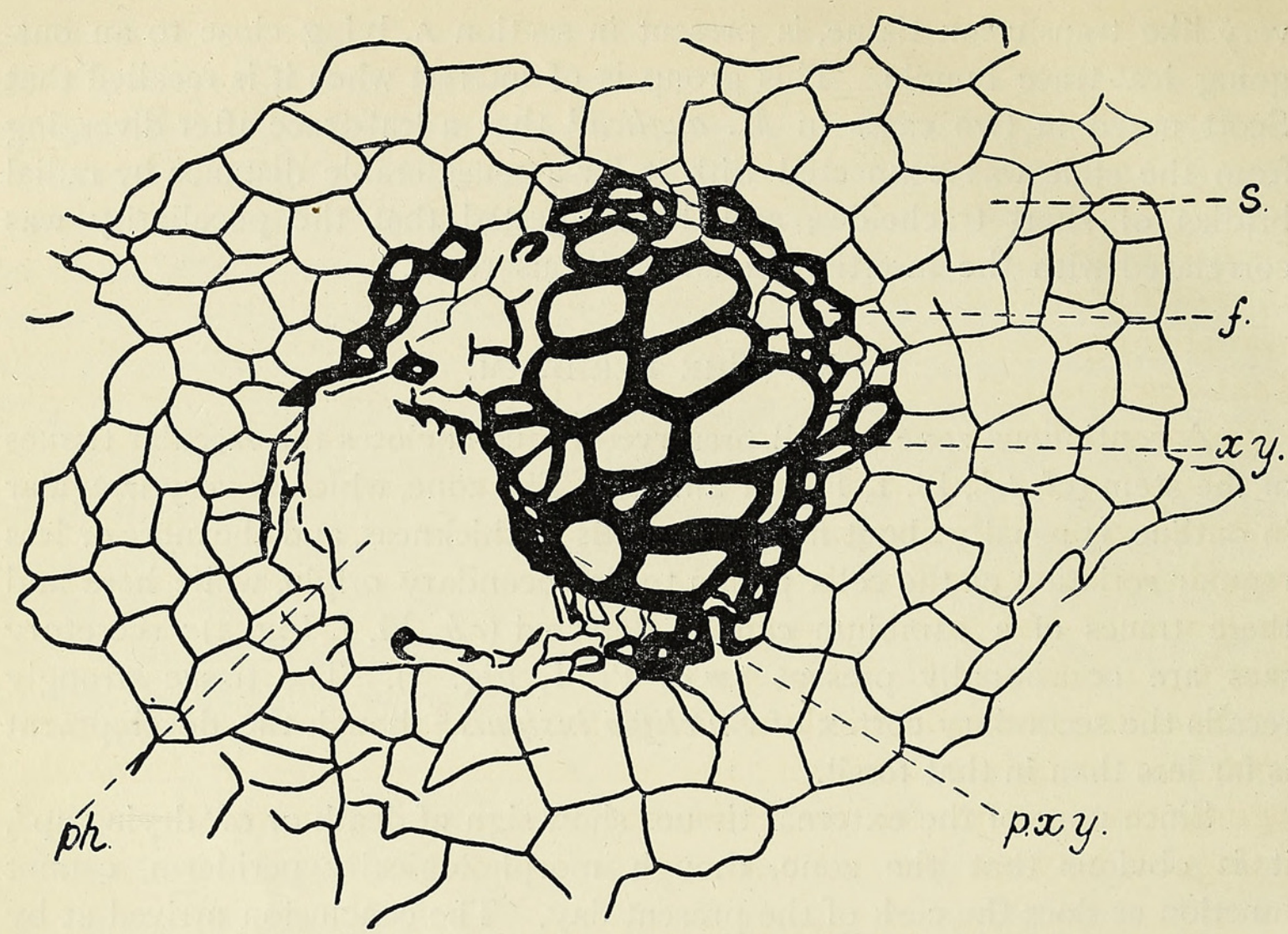

TeXt-Fig 4. Transverse section of a leaf-trace bundle. $\times$ 105. $p h .=$ phloem space; $p x y .=$ protoxylem $; x y .=$ xylem $; f_{0}=$ fibres $; s .=$ sheath.

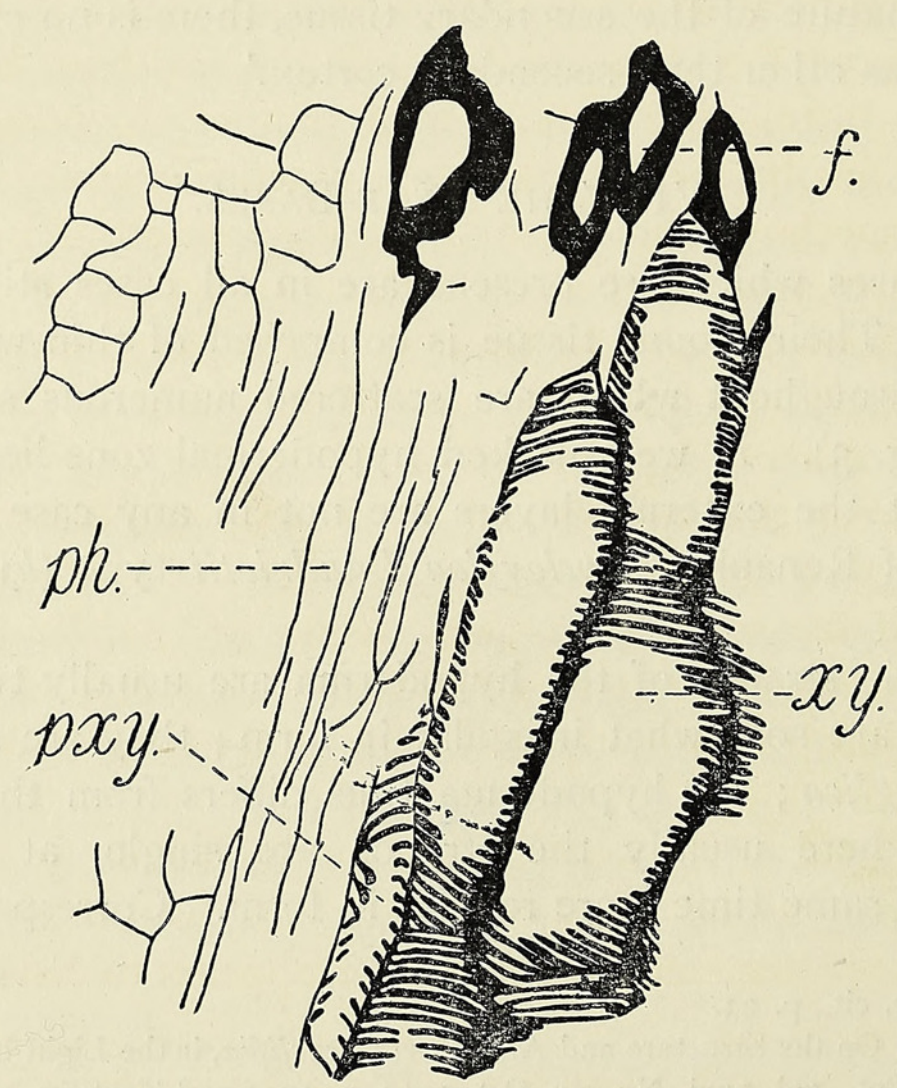

TEXT-FIG. 5. Oblique longitudinal section of part of a leaf-trace bundle. $\times 132 \cdot 5 \cdot$ $p x y .=$ protoxylem $; x y .=$ xylem $; p h .=$ badly preserved phloem elements $; f_{0}=$ fibres. 
difference in size in the three species there appears to be a difference in the development of the hypodermal layers of the leaf-bases.

Very numerous leaf-trace strands are scattered throughout the ground tissue of the leaf-bases; they appear to be orientated in no definite manner, and branching and anastomosing of the bundles occasionally occurred (P1. I, Fig. 3).

Each leaf-trace strand is collateral in type; the phloem is almost invariably represented by a space, on which the exarch protoxylem abutted (Text-figs. 4 and 5). The xylem consists of spirally thickened tracheides; it is surrounded by a single layer of thick-walled fibres, as in $M$. pusilla. ${ }^{1}$

Many of the leaf-trace strands are surrounded by a sheath of wellpreserved cells, differing somewhat in appearance from the cells of the ground tissue; the cells of this sheath show in places a regular seriation of the elements, and in many cambial divisions are taking place. (Cf. s. in Text-fig. 4 with $s$. in P1. I, Fig. 3.)

Speaking generally, the hypoderma, the vascular strands, and the gum canals are so closely similar in the new specimen to those in Medullosa anglica, that except for the difference in size it would be difficult to distinguish between the leaf-bases of the two fossils.

\section{AfFinities.}

With regard to the affinities of the new specimen there is little to say, for the general organization of the stem, with its adherent leaf-bases entirely clothing the surface; the close similarity of the leaf-base, both in general structure and in histological details, with that of Medullosa anglica and $M$. pusilla; and finally, the agreement in practically every detail between the steles of the specimen and those of $M$. anglica and $M$. pusilla, leave no doubt as to its very close relationship with those fossils.

There are, however, certain features which serve to distinguish the specimen from these species. The size of the stem is distinctly smaller than that of any described specimen of $M$. anglica, and it appears to be intermediate between that species and $M$. pusilla: the dimensions given by Scott ${ }^{2}$ for $M$. anglica are $10.5 \times 3.7 \mathrm{~cm}$., the present specimen as nearly as can be estimated measures $5 \times \mathrm{I} \cdot 5 \mathrm{~cm}$., while $M$. pusilla is $2 \cdot 2 \times \mathrm{I} \cdot 3 \mathrm{~cm}$. Little importance would be attached to such a character considered alone, but, taken in conjunction with the following differences, it may possibly be of some diagnostic value.

The arrangement of the leaves could not be definitely determined, but it does not appear to be consistent with the two-fifths phyllotaxis of Medullosa anglica ${ }^{3}$ the stem in $M$. pusilla appears to have been covered

$1 M$. pusilla, loc. cit., p. 225.

$2 M$. pusilla, loc. cit., pp. 22 I-2.

3 It is possible that this may be a local peculiarity, and that the phyllotaxis may prove to be two-fifths when further specimens are available for examination; such a local variation in the leaf arrangement is not uncommon among living plants. 
with three adherent leaf-bases, but four are present in the new specimen. A more important feature is the absence of any secondary tissues accompanying the leaf-trace on its passage from the stele into the cortex, a peculiarity which the specimen appears to share with $M$. pusilla.

The most distinctive character, however, is the organization of the stem steles into an outer ring of three or four steles, enclosing a central strand or star-ring : it is chiefly on account of this feature-a feature which may be considered as a foreshadowing of the structures so characteristic of the Permian members of the genus-that the specimen has been distinguished by a specific name $;^{1}$ at the same time there can be no doubt that the three species are very closely related.

In an account of the genus Medullosa by Weber and Sterzel, ${ }^{2}$ the then known specimens of the genus were arranged in groups or form-cycles. Each form-cycle consisted of a typical species and included those specimens which were either varieties of the type or species closely related to it. Up to I 896 four of these form-cycles were recognized-namely those of Medullosa stellata, Cotta; $M$. porosa, Cotta; $M$. Solmsii, Schenk; and M. Leuckarti, Göpp. \& Stenz.; the species of the genus provided by the English Coal Measures would appear to furnish a fifth, with $M$. anglica, Scott, as the type and the new specimen and $M$. pusilla ${ }^{3}$ as closely allied species.

It has already been pointed out by $\operatorname{Scott}^{4}$ that $M$. anglica approaches most closely to $M$. Leuckarti among the Permian Medulloseae, not only on account of the structure of the individual steles, but also because of the close agreement in leaf characters; moreover, $M$. anglica, $M$. pusilla, and $M$. Leuckarti appear to be the only hitherto described species in which secretory canals occur. ${ }^{5}$ Finally, it is of interest to note in this connexion that the number of star-rings may be very few in $M$. Leuckarti; indeed, the specimen figured by Weber and Sterzel ${ }^{6}$ with three peripheral sinuous steles enclosing five 'Sternringe' offers a striking comparison with the new specimen.

In conclusion, I am glad to take this opportunity to express my gratitude to Professor F. W. Oliver, in whose laboratory at University College, London, this investigation was carried out, not only for handing over the slides to me for description, but also for the advice he has given me during the course of the work.

1 If the protoxylem of the steles should prove to be exarch, this would provide a further feature distinguishing the stem from $M$. anglica.

2 Loc. cit.

${ }^{3}$ Scott: $M$. pusilla, loc. cit.

${ }^{4}$ Scott : $M$. anglica, loc. cit., p. II 4-5.

${ }_{5}$ Bancroft, N.: III. Rhexoxylon africanum, a new Medullosean Stem. Trans. Linn. Soc., Lond., Ser. 2, Bot., vol. viii, Pt. 2, I9I3.

${ }^{6}$ Loc. cit., Tafel V, Fig. 2. 
VIII. DIAGNosis.

Medullosa centrofilis, sp. nov.

Stem small, $5 \times \mathrm{I} .5 \mathrm{~cm}$, including the leaf-bases, completely clothed by spirally arranged, decurrent leaf-bases, four in number.

Vascular system of the stem composed of a ring of three or four steles, irregular in transverse section, enclosing a central star-ring. Interior of each stele occupied by primary wood. ${ }^{1}$

Secondary wood developed round each of the steles. Tracheides with bordered pits on the radial walls.

Leaf-traces leave the stele without any secondary wood; branching almost immediately into collateral strands.

Leaf-bases with the structure of Myeloxylon Landriotii, Ren.

Secretory canals abundant in the leaf-bases and around the steles of the stem.

Locality. Shore Littleborough Colliery, Lancashire.

Horizon. Lower Coal Measures.

The characters in which the species differs from both $M$. anglica and $M$. pusilla are italicized. It also differs from $M$. anglica in the absence of secondary tissues in the leaf-trace, and from $M$. pusilla in the structure of the hypoderma.

\section{Summary.}

I. Structure (Sections ii-vi, pp. 252-26I). The specimen consisted of a stem entirely clothed by portions of four spirally arranged, adherent leaf-bases.

(a) Stem.

The vascular system consists of an outer series of three or four uniform steles, surrounding a single, central star-ring. The structure of the steles and of the star-ring is essentially similar to that of a single stele of Medullosa anglica. The steles are surrounded by a well-preserved zone of tissue, morphologically periderm, but functionally secondary cortex.

Leaf-trace strands are given off from the peripheral region of the outer stelar ring. They are not accompanied in their exit by secondary tissue, and immediately begin to divide up into collateral bundles.

(b) Leaf-base.

The ground tissue consists of thin-walled parenchyma, in which numerous mucilage sacs occur.

Many leaf-trace strands occur in the ground tissue; they are collateral, with exarch protoxylem abutting on a space representing the phloem. A single layer of fibres surrounds the xylem, and most of the strands are enclosed in a sheath, in the cells of which cambial divisions occur.

1 Protoxylem probably exarch. 
The hypodermal zone is of Renault's Myeloxylon Landriotii type.

2. Affinities (Section vii, pp. 26I-262). There is close agreement with Medullosa anglica and $M$.pusilla, not only in general organization but in the details of the leaf-base structure and of the vascular system of the stem. The small size, the differing phyllotaxy, the absence of secondary tissues from the leaf-trace when emerging from the stele, and, more particularly, the presence of the central star-ring, are the main reasons for assigning specific rank to the specimen.

The fossil is regarded as belonging to the same 'form-cycle' as Medullosa anglica and $M$. pusilla. The central star-ring foreshadows the type of structure characteristic of the Permian members of the genus, and more particularly such a type as $M$. Leuckarti.

\section{LITERATURE.}

BAncroft, N.: III. Rhexoxylon africamum, a new Medullosean Stem. Trans. Linn. Soc. Lond., Ser. 2, Bot., vol. viii, Pt. II, I913.

DE Fraine, E.: On the Structure and Affinities of Sutcliffia, in the Light of a newly discovered Specimen. Ann. of Bot., vol. xxvi, No. civ, Oct. I9I 2.

Göppert, H. R., and Stenzel, G.: Die Medulloseae. Eine neue Gruppe der fossilen Cycadeen. Kassel, I88I.

Kiscri, M. H.: The Physiological Anatomy of the Periderm of Fossil Lycopodiales. Ann. Bot., vol. xxvii, No. cvi, April, I9r3.

Scott, D. H. : Studies in Fossil Botany, 2nd ed., Pt. II, I909.

: On the Structure and Affinities of Fossil Plants from the Palaeozoic Rocks. III. On Medullosa anglica, a new Representative of the Cycadofilices. Phil. Trans. Roy. Soc., Ser. B, vol. cxci, I899.

: On Medullosa pusilla. Proc. Roy. Soc., B., vol. lxxxvii, I9I4.

Seward, A. C.: On the genus Myeloxylon (Brong.). Ann. of Bot., vol. vii, p. I, March, I893. Weber, O., and Sterzel, J. T. : Beiträge zur Kenntniss der Medulloseae. Ber. der naturw. Ges. zu Chemnitz, vol. xvii, I896.

Worsdell, W. C. : The Structure and Origin of the Cycadaceae. Ann. of Bot., vol. xx, April, I906.

\section{EXPLANATION OF PLATE XV.}

Illustrating Dr. E. de Fraine's paper on Medullosa centrofilis.

The photographs were taken by Mr. F. Pittock, of the Zoological Department, University College, London.

$a, \quad \beta, \gamma, \gamma^{1}$ and $\gamma^{2}=$ steles : $\delta=$ star-ring; $l b .{ }^{1}, \quad l b .{ }^{2}, \quad l b .^{3}$, and $l b . .^{4}=$ leaf-bases; $s c .^{1}$, $s c_{0}{ }^{2}=$ sclerenchyma fibres ; $s c . b_{0}=$ fibrous zone; $h y_{0}=$ hypoderma $; p d_{0}=$ periderm $; l t_{0}=$ leaftrace; st. $=$ stele; $m . c_{.}=$secretory canal $; s .=$ sheath $; c . b .=$ cambium.

Fig. I. Transverse section of stem (Section A), showing three of the leaf-bases: part of leafbase I (on the right) omitted. $\times 2.5$.

Fig. 2. Transverse section of the stem (Section 9 ). $\times 2 \cdot 5$.

Fig. 3. Part of Section B, showing part of leaf-base $l b .{ }^{2}$ cut off by the sclerenchyma zone $s c .^{2} \cdot \times 17 \cdot 5 \cdot$

Fig. 4. Leaf-trace I which has just emerged from the stele, st.; a second leaf-trace, $l t{ }^{2}$, has divided. From section $8 . \times 17 \cdot 5$ 
Annats of Botany,

26.3

ind $x$

(t)

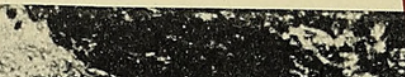

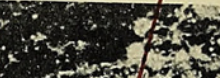

(3)

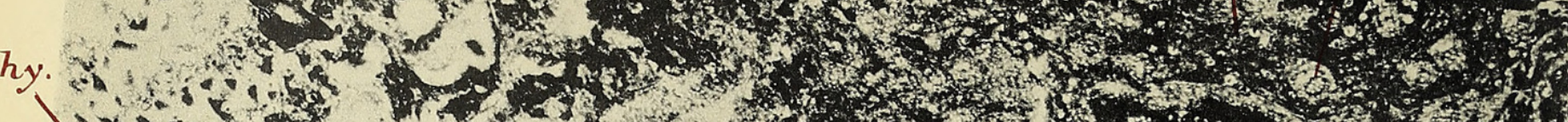

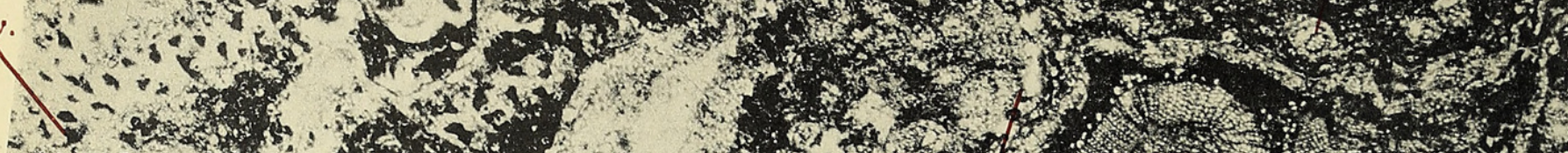
En 6.

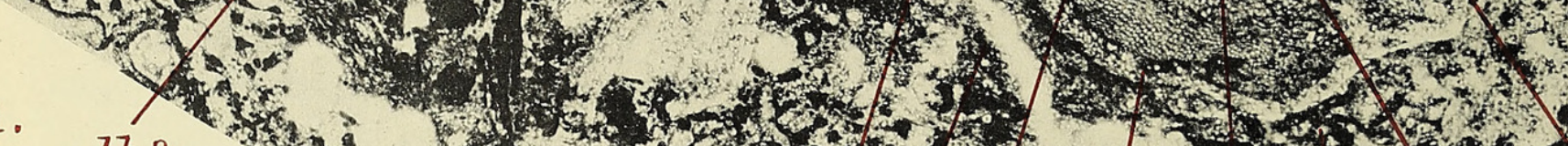
1. 2b.2. 2.

\section{hy.}

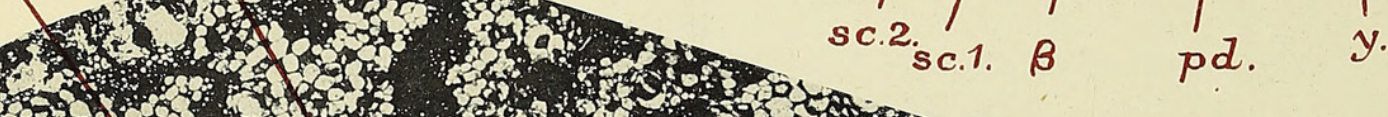

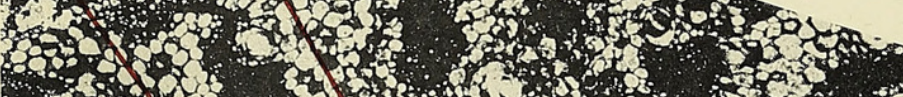

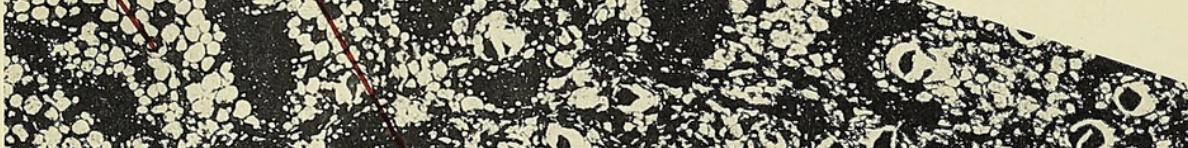

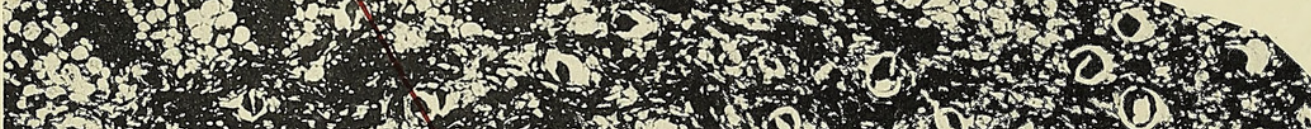

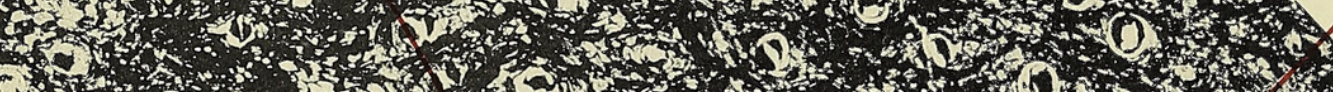

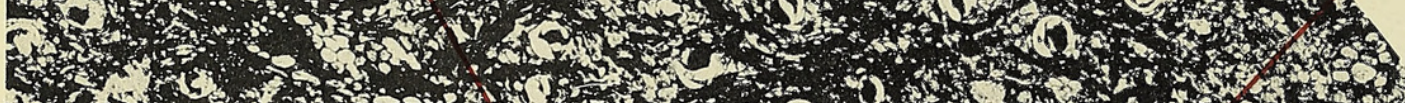

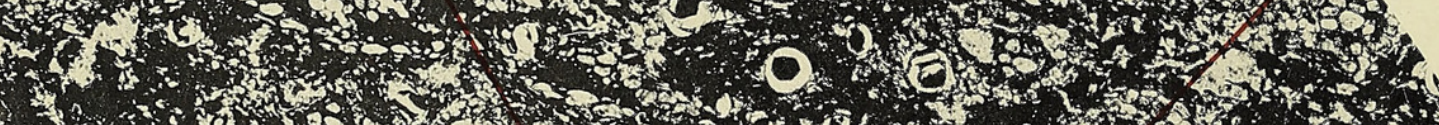

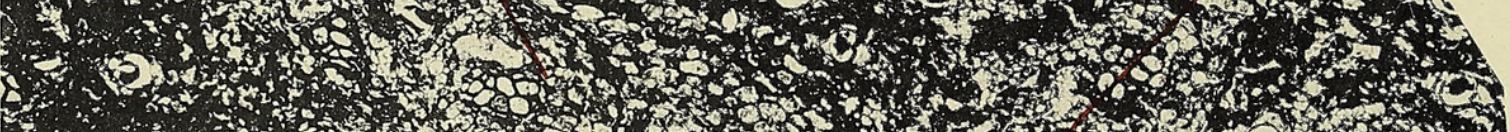

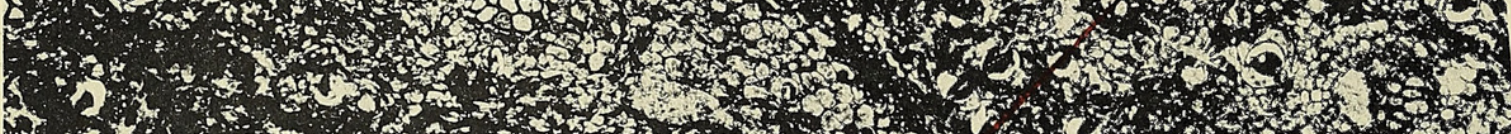

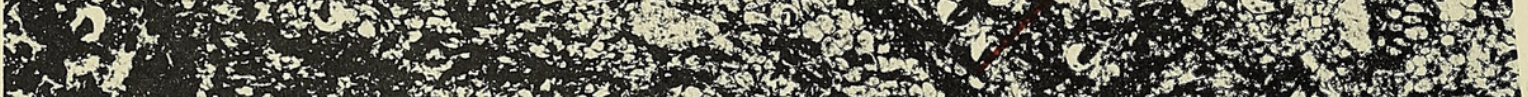

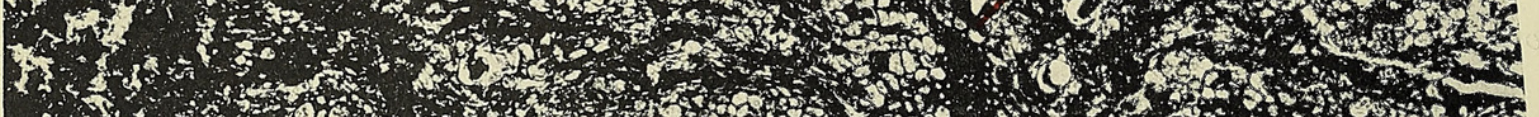

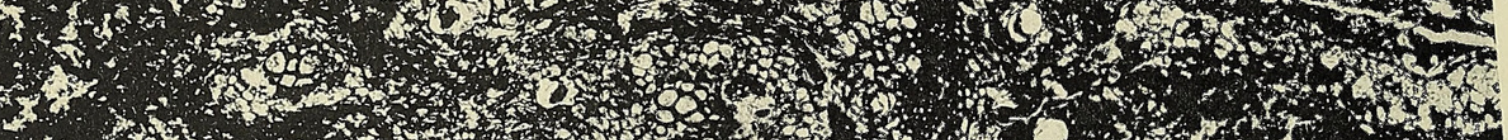
3
3

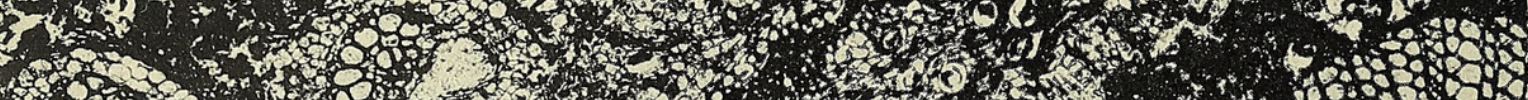

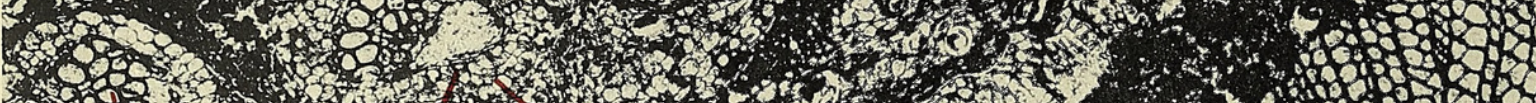

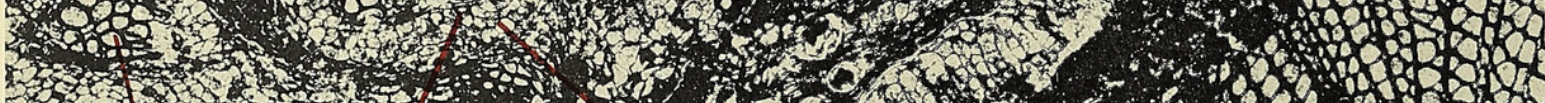

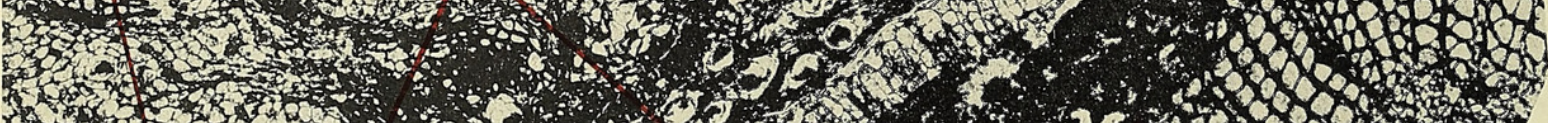

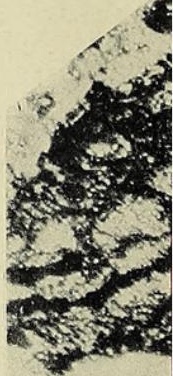

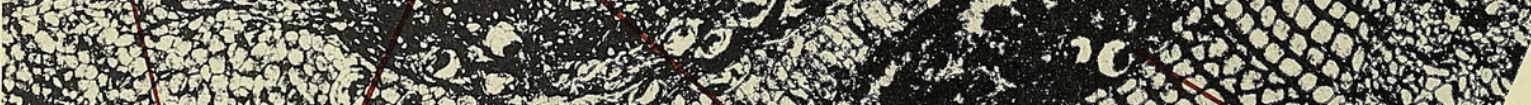

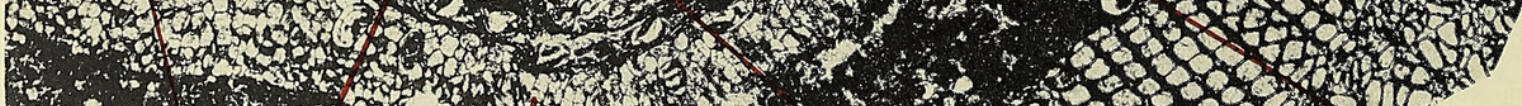

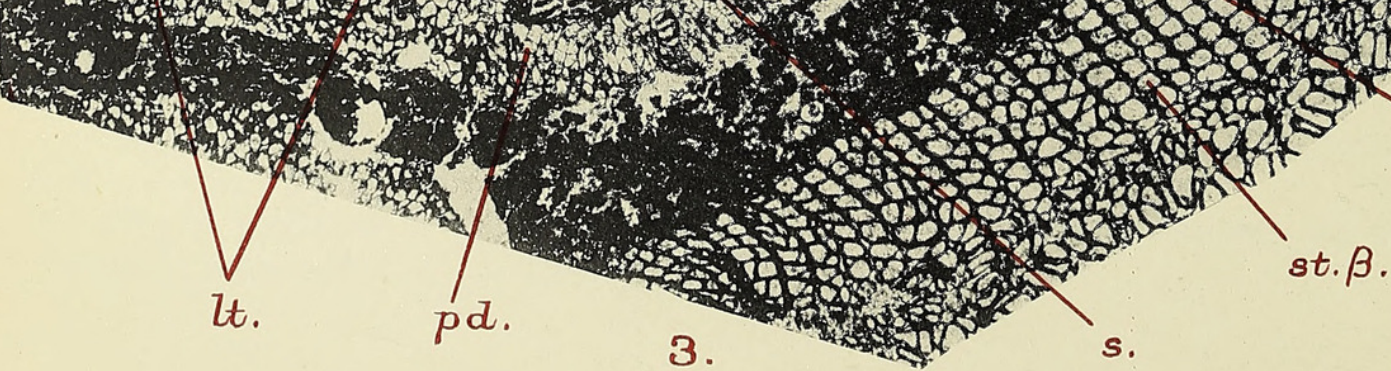




\section{3.

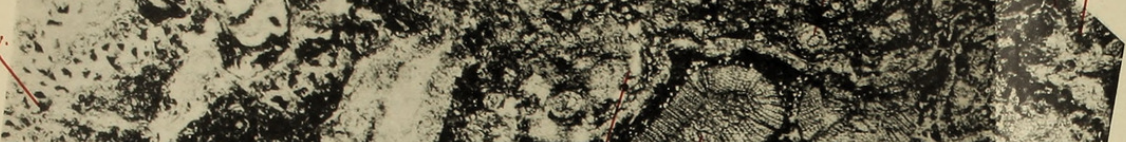

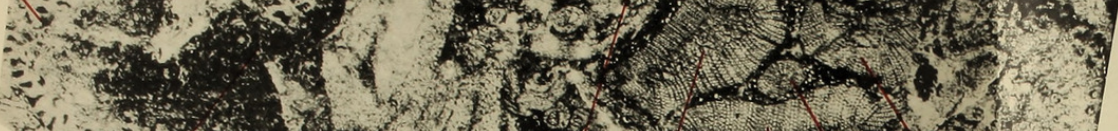

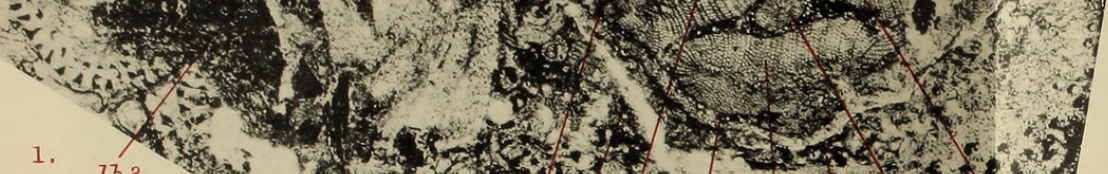

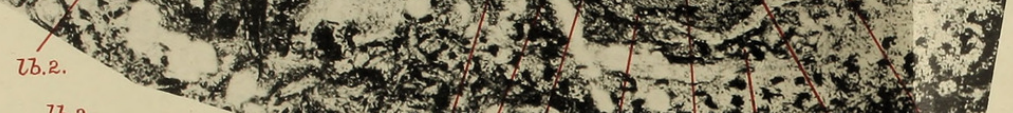

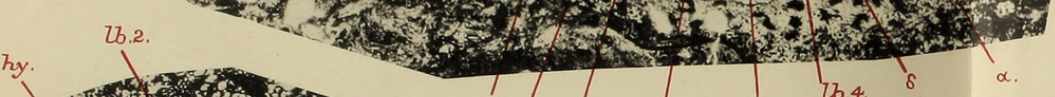

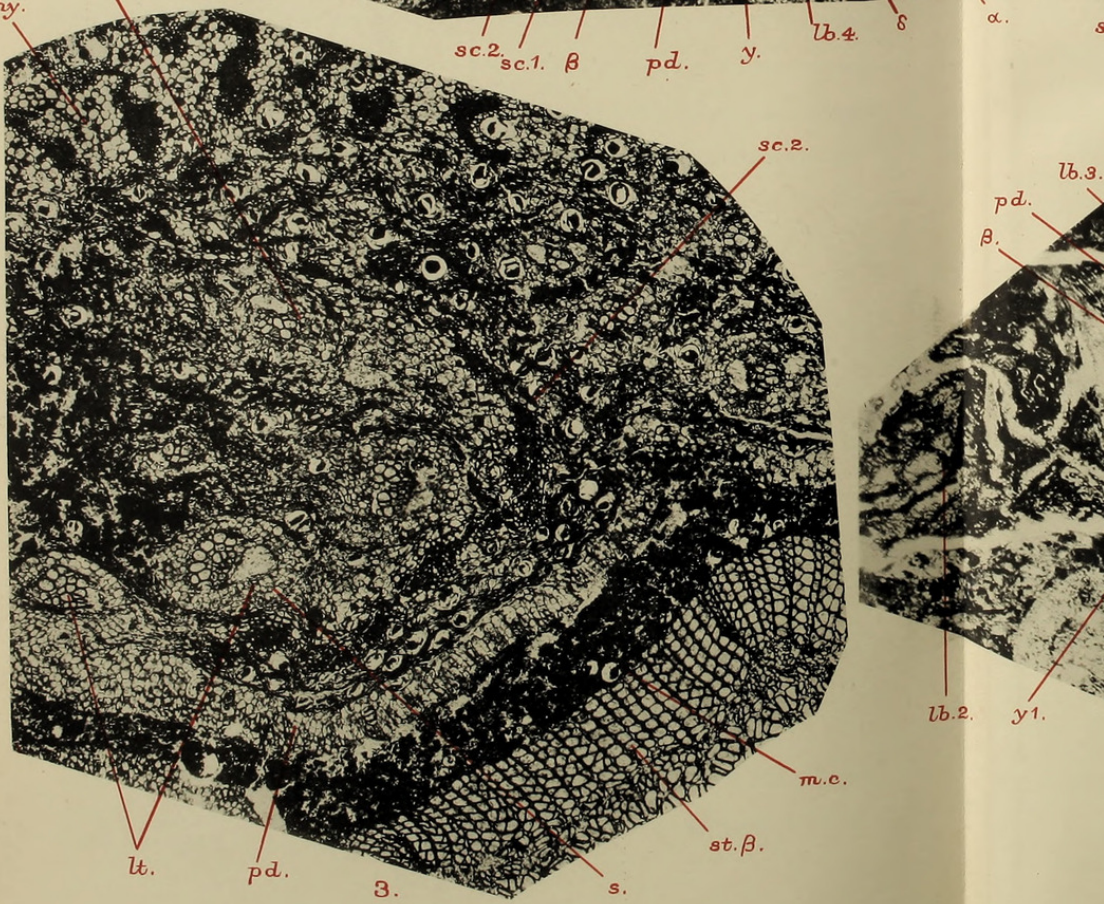

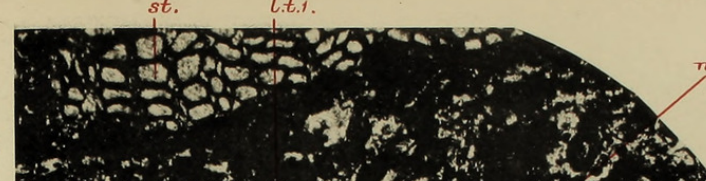

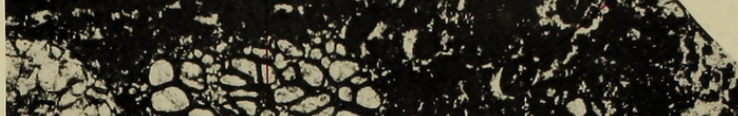

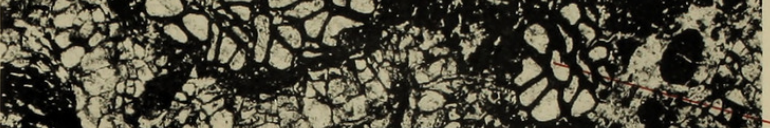

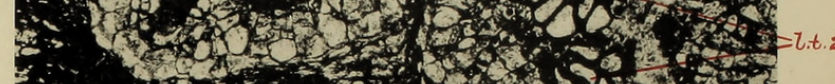

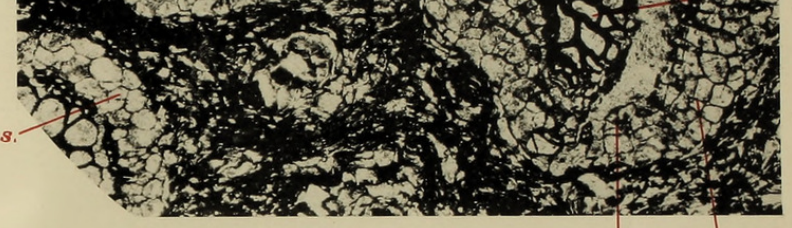
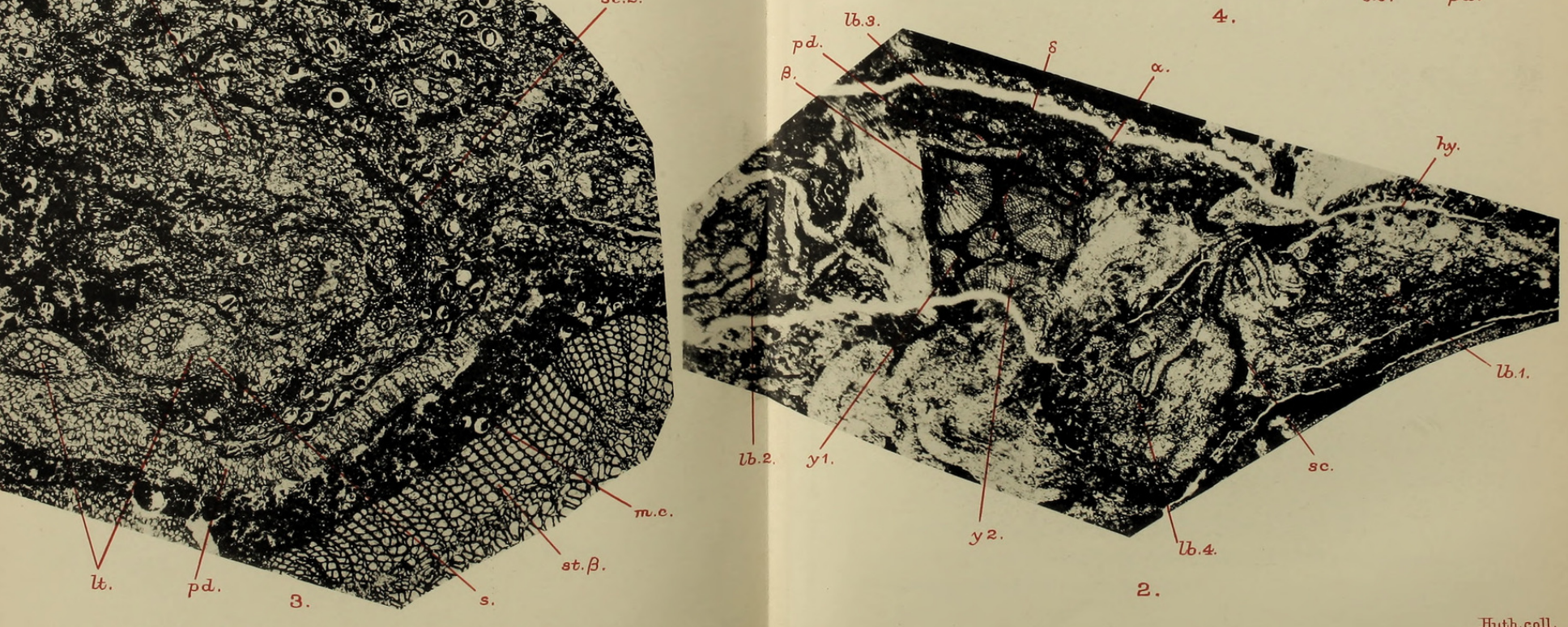

DE FRAINE - MEDULLOSA CENTROFILIS. 


\section{$2 \mathrm{BHL}$ Biodiversity Heritage Library}

De Fraine, E. 1914. "On Medullosa centrofilis, a new species of Medullosa from the lower coal measures." Annals of botany 28, 251-264. https://doi.org/10.1093/oxfordjournals.aob.a089502.

View This Item Online: https://www.biodiversitylibrary.org/item/236856

DOI: https://doi.org/10.1093/oxfordjournals.aob.a089502

Permalink: https://www.biodiversitylibrary.org/partpdf/320020

\section{Holding Institution}

Smithsonian Libraries

\section{Sponsored by}

Biodiversity Heritage Library

\section{Copyright \& Reuse}

Copyright Status: Not in copyright. The BHL knows of no copyright restrictions on this item.

This document was created from content at the Biodiversity Heritage Library, the world's largest open access digital library for biodiversity literature and archives. Visit BHL at https://www.biodiversitylibrary.org. 